\title{
ULTRAVIOLET - VISIBLE - NEAR INFRARED SPECTROSCOPY FOR RAPID DETERMINATION OF VOLATILE COMPOUNDS IN WHITE GRAPES DURING RIPENING
}

\author{
ESPECTROSCOPIA ULTRAVIOLETA - VISÍVEL - INFRAVERMELHO PRÓXIMO PARA \\ DETERMINAÇÃO RÁPIDA DE COMPOSTOS VOLÁTEIS EM UVAS BRANCAS DURANTE A \\ MATURAÇÃO
}

\author{
Gabriel Ripoll ${ }^{1}$, Manuel Vazquez ${ }^{1}$, Mar Vilanova ${ }^{2 *}$ \\ ${ }^{1}$ Department of Analytical Chemistry, University of Santiago de Compostela, Lugo, Spain. \\ ${ }^{2}$ Misión Biológica de Galicia. Spanish National Research Council (CSIC). El Palacio-Salcedo, 36143, Pontevedra, Spain. \\ *Corresponding author: Tel.: + 34 986854800, e-mail: mvilanova@mbg.csic.es
}

(Received 28.09.2016. Accepted 19.01.2017)

\section{SUMMARY}

Near Infrared (NIR) spectroscopy is increasingly used in food analysis due to its speed and ease of use. Ultraviolet-visible (UV-VIS) spectroscopy is commonly used in any laboratory worldwide. The objective of this work was to develop a rapid method based on UV-VIS-NIR spectroscopy for the determination of volatile compounds in white 'Albariño' grapes from DO Rias Baixas (Spain). A total of 52 samples of white 'Albariño' must were analysed. Gas chromatography-mass spectrometry (GC-MS) was used as reference method. Partial Least Squares regression was used to fit mathematical models to relate the UV-VIS-NIR spectra with the volatile compounds determined by GC-MS. Reliable models for predicting the following compounds were obtained: (E)-2-hexenal, 1-hexanol, (Z)-2-hexanol, benzaldehyde, phenylethanal, cis pyran linalool oxide and 2phenylethanol. The best performance was obtained using pre-treated spectral data ( $1^{\text {st }}$ and $2^{\text {nd }}$ derived). The $r^{2}$ coefficients obtained were greater than 0.85 for these compounds. In conclusion, UV-VIS-NIR spectroscopy is a fast and feasible method for the determination of some volatile compounds in white ‘Albariño’ musts from DO Rías Baixas.

\section{RESUMO}

A espectroscopia de infravermelho próximo (NIR) é cada vez mais utilizada na análise de alimentos devido à sua rapidez e facilidade de uso. A espectroscopia ultravioleta - visível (UV-VIS) é comumente usada em qualquer laboratório em todo o mundo. O objetivo deste trabalho foi desenvolver um método rápido baseado na espectroscopia UV-VIS-NIR para a determinação de compostos voláteis em uvas brancas 'Albariño' da DO Rias Baixas (Espanha). Foram analisadas 52 amostras de mosto 'Albariño’ branco. A cromatografia gasosa-espectrometria de massa (GCMS) foi utilizada como método de referência. A regressão Parcial dos Mínimos Quadrados foi usada para ajustar modelos matemáticos com o intuito de relacionar os espectros UV-VIS-NIR com os compostos voláteis determinados por GC-MS. Obtiveram-se modelos fiáveis para prever os seguintes compostos: (E) -2-hexenal, 1-hexanol, (Z) -2-hexanol, benzaldeído, feniletanal, óxido de cis-pirano linalol e 2-feniletanol. O melhor desempenho foi obtido usando os dados espectrais pré-tratados ( $1^{\mathrm{a}}$ e $2^{\mathrm{a}}$ derivadas). Os coeficientes $\mathrm{r}^{2}$ obtidos foram superiores a 0,85 para estes compostos. Em conclusão, a espectroscopia UV-VIS-NIR é um método rápido e viável para a determinação de alguns compostos voláteis em mostos brancos da casta ‘Albariño’ da DO Rías Baixas.

Key words: volatile compounds, UV-VIS-NIR spectroscopy, rapid method.

Palavras-chave: compostos voláteis, espectroscopia UV-VIS-NIR, método expedito.

\section{INTRODUCTION}

Grape composition at harvest is one of the most important factors determining the future quality of wine. Volatiles, important flavour components in white wine, are formed during grape berry metabolism and they are very influenced by the ripening stage. Measurement of grape volatile composition in the last ripening stages is an important requirement for an optimum production of white

Paper submitted in a preliminary version to II Symposium Nacional de Ingeniería Hortícola - Almería 2016.

This is an Open Access article distributed under the terms of the Creative Commons Attribution License

(http://creativecommons.org/licenses/by/4.0), which permits unrestricted use, distribution, and reproduction in any medium, provided the original work is properly cited. 
wines. Therefore a rapid method is necessary to know the aromatic ripening of grape.

Several authors have reported the use of NIR spectroscopy to measure total soluble solids (TSS) in grapes (Shenk et al., 1992; Osborne et al., 1993; Gishen and Dambergs, 1998; Gishen et al., 2000; Dambergs et al., 2003a; Arana et al., 2005) or ethanol, tartaric acid and malic acid in wines (Martelo-Vidal and Vázquez, 2015). Some authors have studied and developed Vis-NIR or NIR nondestructive systems in order to determine technological parameters useful for classifying grapes (Gishen and Dambergs, 1998; Dambergs et al., 2003b; Herrera et al., 2003; Cabassi et al., 2006; Casiraghi et al., 2006; Dambergs et al., 2006). VisNIR spectroscopy has also been used to predict TSS, $\mathrm{pH}$, total anthocyanins and polyphenolic compounds in red grapes by several authors (Dambergs et al., 2003a; Cozzolino et al., 2004; Martelo-Vidal and Vázquez, 2014). NIR also was used to measure volatile aroma compounds in Riesling wine (Smith et al., 2008). However, NIR spectroscopy has never been applied to know the volatile composition of grapes during ripening.

'Albariño' is one of the most important white grape varieties in Galicia (NW Spain). The aim of this work was to apply of UV-Vis-NIR spectroscopy to predict the volatile composition of grapes during ripening with the objective of optimizing the wine aroma.

\section{MATERIAL AND METHODS}

\section{Vineyard locations and grape samples}

This study was tested on 'Albariño' grapes grown on the Controlled Designation of Origin Rías Baixas (Galicia, Spain). A total of 52 grape samples of Vitis vinifera 'Albariño' were studied at different maturity stages, 13 from M-1 (16.3 ${ }^{\circ}$ Brix), 19 from M-2 (17.8 ${ }^{\circ}$ Brix) and 20 from M-3 (18.7 ${ }^{\circ}$ Brix). The grape samples (1 kg) were collected during 2014 vintage. After harvest, ${ }^{\circ}$ Brix was analyzed by refractometry and the samples were immediately frozen and stored at $-20^{\circ} \mathrm{C}$ until chemical analyses. Grape samples of $500 \mathrm{~g}$ were used to analyze free volatile composition of 'Albariño' musts.

\section{Extraction, identification and quantification of free volatile compounds}

About $500 \mathrm{~g}$ of frozen berries were thawed at $4{ }^{\circ} \mathrm{C}$ overnight, and then manually crushed, centrifuged (9287 rpm, $20 \mathrm{~min}, 4^{\circ} \mathrm{C}$ ) and filtered through a glass wool bed. To $75 \mathrm{~mL}$ of juice 4-nonanol (Merck, ref. 818773) was added as internal standard $(10 \mu \mathrm{L}$ of 40 $\mu \mathrm{g} / \mathrm{L}$ solution in $10 \%, \mathrm{v} / \mathrm{v}$ ethanol) and passed through a LiChrolut EN cartridge (Merck, $500 \mathrm{mg}$, 40-120 $\mu \mathrm{m}$ ) according to Oliveira et al. (2000). The resin was previously pre-conditioned with $10 \mathrm{~mL}$ of dichloromethane, $5 \mathrm{~mL}$ of methanol and $10 \mathrm{~mL}$ of aqueous alcoholic solution $(10 \%$, v/v). Free volatile compounds were eluted with $5 \mathrm{~mL}$ of pentanedichloromethane. The pentane-dichloromethane elute was dried over anhydrous sodium sulphate and concentrated to $200 \mu \mathrm{L}$ by solvent evaporation under a nitrogen stream prior to analysis.

Gas chromatographic analysis of volatile compounds was performed using a GC-MS system constituted by an Agilent Chromatograph 6890N and an ion-trap mass spectrometer 5975C. A $1 \mu \mathrm{L}$ injection was made into a capillary column, coated with CP-Wax $52 \mathrm{CB}$ $(50 \mathrm{~m} \times 0.25 \mathrm{~mm}$ i.d., $0.2 \mu \mathrm{m}$ film thickness, Chrompack). The temperature of the injector (SPIseptum-equipped programmable temperature) was programmed from $20^{\circ} \mathrm{C}$ to $250{ }^{\circ} \mathrm{C}$, at $180{ }^{\circ} \mathrm{C} / \mathrm{min}$. The oven temperature was held at $40{ }^{\circ} \mathrm{C}$ for $5 \mathrm{~min}$, then programmed to rise from $40{ }^{\circ} \mathrm{C}$ to $250{ }^{\circ} \mathrm{C}$ at 3 ${ }^{\circ} \mathrm{C} / \mathrm{min}$, then held $20 \mathrm{~min}$ at $250{ }^{\circ} \mathrm{C}$ and finally programmed to go from $250{ }^{\circ} \mathrm{C}$ to $255^{\circ} \mathrm{C}$ at $1{ }^{\circ} \mathrm{C} / \mathrm{min}$. The carrier gas was helium N60 (Air Liquide) at 103 $\mathrm{kPa}$, which corresponds to a linear speed of $180 \mathrm{~cm} / \mathrm{s}$ at $150{ }^{\circ} \mathrm{C}$. The detector was set to electronic impact mode $(70 \mathrm{eV})$, with an acquisition range from 29 to $360 \mathrm{~m} / \mathrm{z}$, and an acquisition rate of $610 \mathrm{~ms}$.

Identification was performed using the software Saturn version 5.2 (Varian), by comparing mass spectra and retention indices with those of pure standard compounds. All of the compounds were quantified as 4-nonanol equivalents.

\section{Spectral analysis}

Samples of musts (5 mL) were analysed in a spectrophotometer V-670 (Jasco Inc, Japan) using transmittance mode at $2 \mathrm{~nm}$ intervals in UV-VIS-NIR regions (190 nm-2500 nm). Prior spectral analysis, samples were equilibrated at $33{ }^{\circ} \mathrm{C}$ for $10 \mathrm{~min}$ before scanning and filtered through $0.45 \mu \mathrm{m}$ filter (Cozzolino et al., 2007). Cell quartz with $1 \mathrm{~mm}$ path length was used to scan samples. Data were collected using Spectra Manager ${ }^{\mathrm{TM}}$ II software (Jasco Inc, Japan). Samples were scanned in duplicate obtaining 104 spectra.

\section{Chemometric analysis}

The chemometric analysis was performed according to Martelo-Vidal and Vazquez (2014). Spectral data were exported from Spectra Manager ${ }^{\mathrm{TM} I I}$ software into Uncrambler software (version X 10.2; CAMO, Oslo, Norway) for pre-treatment and obtain calibration models. Two replicates of each sample (104 spectra) were analysed in Unscrambler software. 
Principal Component Analysis (PCA) was performed to detect patterns and outliers (Cozzolino et al., 2011; Cetó et al., 2013; Keckes et al., 2013).

Calibration models for measurement of volatile compounds were performed using partial least square regression (PLS). Calibration models were developed using full-cross validations. Spectral data were pretreated before PLS modeling. The pre-treatments tested were standard normal variate (SNV), first derived Savitzky-Golay ( $1^{\text {st }}$ derived), second derived Savitzky-Golay ( $2^{\text {nd }}$ derived). The statistical parameters Correlation Coefficient-squared $\left(\mathrm{r}^{2}\right)$, Root Mean Square of Calibration (RMSEC), Root Mean Square Error of Cross Validation (RMSECV) and Residual Predictive Deviation (RPD) was used to evaluate how well the calibration model of spectra could predict volatile compounds (Cozzolino et al., 2004, 2011; Lorenzo et al., 2009; Garde-Cerdan et al., 2012).

\section{RESULTS AND DISCUSSION}

\section{Chemical analysis}

'Albariño' cultivar from controlled designation of origin Rías Baixas was sampled at different ripening dates, which influences in the volatile composition.

Table I and Figure 1 shows the variation of concentration volatile compounds identified and quantified in 52 samples of ‘Albariño' musts during 3 stages of ripening (16.3, 17.8 and $\left.18.7^{\circ} \mathrm{Brix}\right)$. Data in Table I have been arranged into the nine chemical families where were identified and quantified 26 free volatile compounds: 6 alcohols, $7 \mathrm{C}_{6 \text {-compounds, } 3}$ volatile acids, 2 terpenes, 2 ethyl esters and acetates, 2 aldehydes, 1 lactone, 2 volatile phenols and 1 carbonyl compound.

Table I

Free volatile composition ( $\mu \mathrm{g} / \mathrm{L}$ ) of ‘Albariño’ musts (mean $+\mathrm{SD}$ ) by ripening stage (expressed in ${ }^{\circ}$ Brix) Composição volátil livre $(\mu g / L)$ de mostos ‘Albariño’ (média $+S D)$ na maturação $\left({ }^{\circ}\right.$ Brix)

\begin{tabular}{|c|c|c|c|}
\hline Compound & M-1 (16.3 ${ }^{\circ}$ Brix $)$ & M-2 (17.8 ${ }^{\circ}$ Brix $)$ & M-3 (18.7 ${ }^{\circ}$ Brix $)$ \\
\hline 1-butanol & $7.38 \pm 4.96$ & $18.51 \pm 16.19$ & $13.57 \pm 7.95$ \\
\hline 2+3-methyl-1-butanol & $7.93 \pm 4.55$ & $75.10 \pm 118.77$ & $92.75 \pm 95.79$ \\
\hline 3 methyl -3- buten-1-ol & $4.12 \pm 1.59$ & $10.03 \pm 5.44$ & $16.86 \pm 12.59$ \\
\hline 2.3-butanodiol & 0.00 & $8.98 \pm 7.05$ & $5.39 \pm 4.02$ \\
\hline Benzylic alcohol & $33.17 \pm 13.11$ & $76.58 \pm 37.61$ & $44.99 \pm 18.37$ \\
\hline 2-Phenylethanol & $81.59 \pm 48.76$ & $991.23 \pm 1754.85$ & $1020.38 \pm 1508.73$ \\
\hline Hexanal & $164.61 \pm 82.32$ & $181.17 \pm 107.80$ & $192.39 \pm 134.59$ \\
\hline (E)-2-hexenal & $255.35 \pm 79.43$ & $550.85 \pm 250.45$ & $455.26 \pm 313.88$ \\
\hline 1-hexanol & $455.68 \pm 231.25$ & $1546.29 \pm 676.89$ & $824.47 \pm 213.42$ \\
\hline (E)-3-hexenol & $6.37 \pm 3.30$ & $18.83 \pm 6.82$ & $16.90 \pm 18.51$ \\
\hline (Z)-3-hexanol & $34.91 \pm 12.29$ & $79.85 \pm 83.79$ & $55.57 \pm 111.21$ \\
\hline (Z)-2-hexanol & $757.21 \pm 401.92$ & $1802.23 \pm 741.22$ & $707.35 \pm 428.31$ \\
\hline (E)-2-hexanol & $10.62 \pm 5.68$ & $30.88 \pm 14.81$ & $22.75 \pm 13.53$ \\
\hline Hexanoic acid & $44.48 \pm 51.28$ & $61.89 \pm 40.34$ & $38.39 \pm 18.68$ \\
\hline (E)-2-hexanoic acid & $17.94 \pm 19.72$ & $20.85 \pm 22.97$ & $13.38 \pm 5.87$ \\
\hline Hexadecanoic acid & $38.23 \pm 18.33$ & $128.00 \pm 122.51$ & $137.09 \pm 82.81$ \\
\hline 2-ethyl-hexanol & $3.12 \pm 2.38$ & $10.50 \pm 12.99$ & $11.04 \pm 6.66$ \\
\hline 2-Phenylethylacetate & $6.37 \pm 5.62$ & $17.47 \pm 17.25$ & $18.47 \pm 17.28$ \\
\hline Benzaldehyde & $3.56 \pm 1.24$ & $26.19 \pm 35.90$ & $18.40 \pm 22.00$ \\
\hline Phenylethanal & $65.44 \pm 66.71$ & $325.70 \pm 574.91$ & $335.04 \pm 305.02$ \\
\hline cis piran linalol & $8.28 \pm 3.31$ & $20.39 \pm 22.63$ & $14.96 \pm 8.31$ \\
\hline Diendiol I & $3.68 \pm 3.92$ & $22.28 \pm 24.56$ & $17.01 \pm 12.07$ \\
\hline Butyrolactone & $37.71 \pm 27.50$ & $31.56 \pm 19.71$ & $31.12 \pm 21.80$ \\
\hline 4-ethylphenol & $10.04 \pm 5.06$ & $19.04 \pm 14.75$ & $25.32 \pm 0.00$ \\
\hline Vanillin & $19.18 \pm 6.93$ & $18.91 \pm 7.27$ & $38.63 \pm 42.87$ \\
\hline Acetoin & $20.37 \pm 14.63$ & $20.30 \pm 14.21$ & $34.42 \pm 37.38$ \\
\hline
\end{tabular}




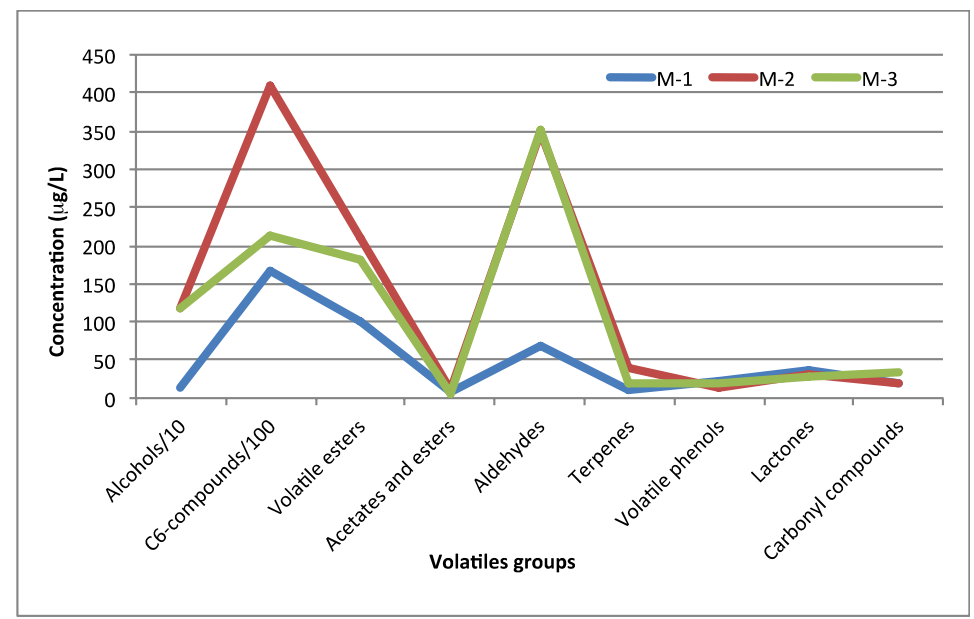

Figure 1. Evolution of volatile compounds families in 'Albariño' cultivar during ripening:

M-1 (16.3 ${ }^{\circ}$ Brix), M-2 (17.8 ${ }^{\circ}$ Brix) and M-3 (18.7 ${ }^{\circ}$ Brix $)$.

Evolução das famílias de compostos voláteis no 'Albariño' durante a maturação

M-1 (16,3 ${ }^{\circ}$ Brix), $H-2\left(17,8^{\circ}\right.$ Brix) e $M-3$ (18,7 ${ }^{\circ}$ Brix).

Analytical results showed differences in the ripening of 'Albariño' cultivar where $\mathrm{C}_{6}$-compounds (represented by six compounds) were quantitatively the largest group of free volatile compounds quantified in 'Albariño' grape cultivar. $\mathrm{C}_{6}$ compounds are related to varietal origin because they can be formed, via $\mathrm{C}_{6}$-aldehydes, through lipoxygenase activity, from linoleic and linolenic acids present in grapes and supply vegetal and herbaceous nuances to the wine (Oliveira et al., 2006; Kalua and Boss, 2009). 'Albariño' was described as a terpenic wine by several authors because the bound terpenic content of the must (Oliveira et al., 2000; Vilanova et al., 2007). However in our work only volatiles (free fraction) were analysed where only cis pyran linalool oxide and diendiol I was identified.
Among ripening data, the highest total value of volatile composition was showed in M-2 (17.8 $\left.{ }^{\circ} \mathrm{Brix}\right)$ with $5.939 \mu \mathrm{g} / \mathrm{L}$. Different behaviour was shown among compounds (Figure 2). Ripening data $\mathrm{M}-2$ showed the highest values of $\mathrm{C}_{6}$-compouds, volatile esters and acetates and terpenes. All volatile families have shown a decreased in the last ripening data (M3) with exception of aldehydes and carbonyl compounds. Volatile phenols and lactones concentration decreased during ripening. The evolution of volatiles during ripening of grape juice was not proportional to the changes in sugar content, which shows that the technological and aromatic maturities did not occur at the same time (Vilanova et al., 2009).

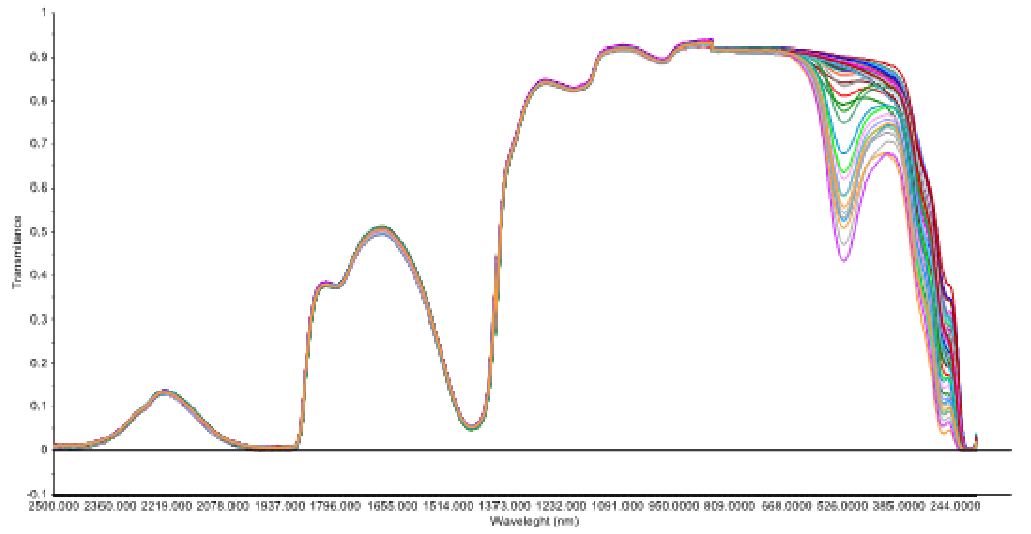

Figure 2. Raw UV-VIS-NIR spectra of ‘Albariño’ white must (DO Rías Baixas). Espectros UV-VIS-NIR de mostos de 'Albariño’ (DO Rías Baixas). 


\section{Spectral analysis}

Figure 2 shows raw UV-VIS-NIR spectral data of 'Albariño' musts samples. UV-VIS zones (234 a 850 $\mathrm{nm})$ showed big differences among samples meanwhile NIR zone (850 a $2500 \mathrm{~nm}$ ) showed more homogeneity. The variability observed in UV-VISNIR could be useful to obtain mathematical models that relate the volatile compounds with the spectra. PLS was performed on raw or pre-treated spectral data with the aim to correlate the volatile compounds and the spectral data. Results showed significant correlations between spectral data and some volatile compounds.

With the aim of showing the variability in volatile composition and spectral data, a score plot of the PCA of UV-VIS-NIR spectra from must samples is shown in Figure 3. This PCA explains $81 \%$ of total variance with the first two PC. Separation among ripening samples was observed in the score plots. Some of the most ripening samples (18.7 ${ }^{\circ}$ Brix, samples 1-19) were located in the positive side of PC1 and negative side of PC2.

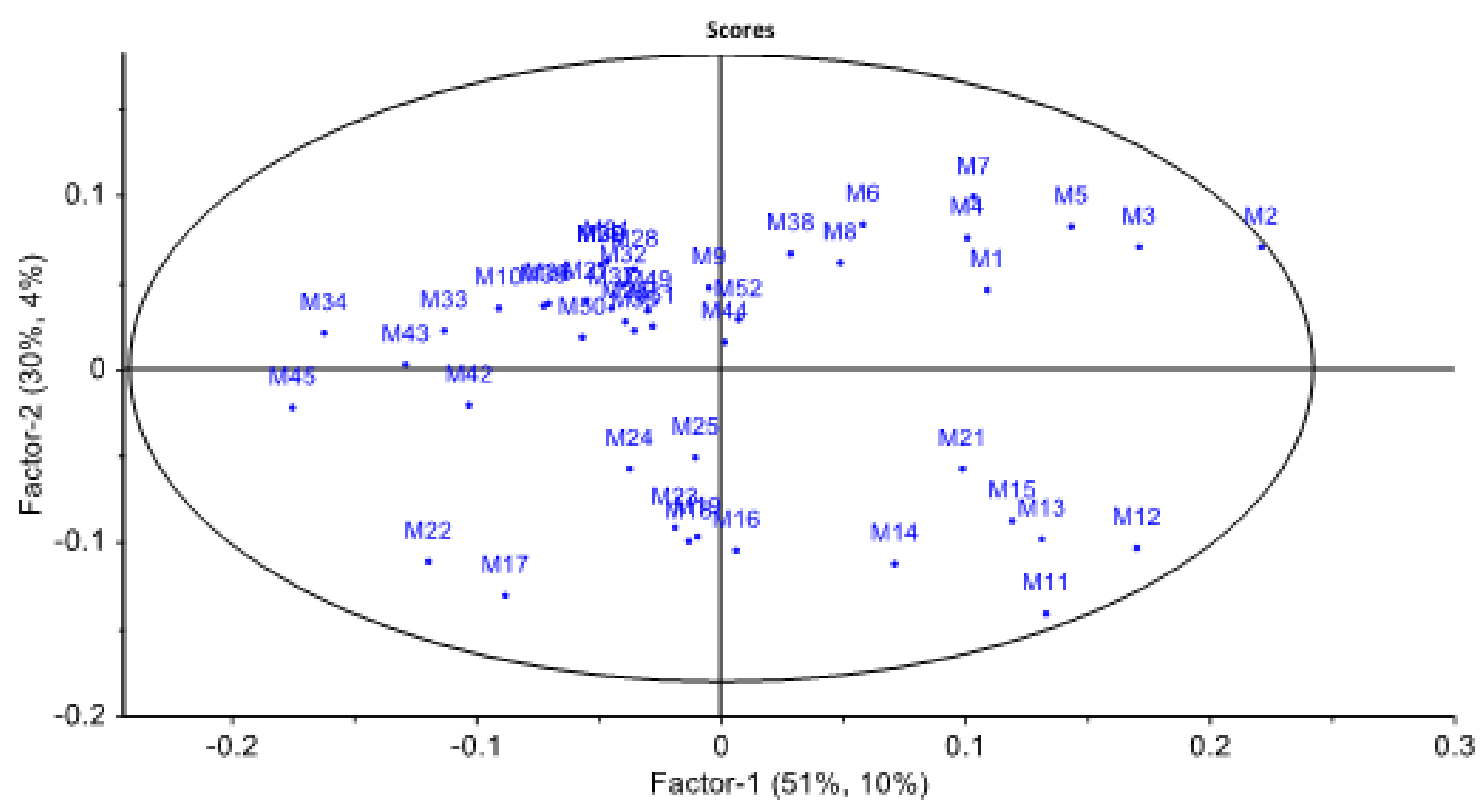

Figure 3. Score plots of two principal components from raw UV-VIS-NIR data of ‘Albariño’ white musts (M1-M52) from DO Rías Baixas.

Análise em componentes principais de dados brutos UV-VIS-NIR de mostos de 'Albariño’ (M1-M52) da DO Rías Baixas.

The PLS analysis showed that UV-VIS-NIR spectra allowed to obtain accurate mathematic models to predict some volatile compounds concentrations from spectral data. Statistical results of the models for volatile compounds and UV-VIS-NIR spectral data (raw and pre-treatments) are shown in Table II. Only statistical results for the model of the best pretreatment are showed.

Results showed variations based on the treatments (raw, $1^{\text {st }}$ derived, $2^{\text {nd }}$ derived or SNV). For many volatile compounds, the best models were obtained with the pre-treatments $1^{\text {st }}$ derived and $2^{\text {nd }}$ derived. For only one compound the best pre-treatment was SNV (vanillin) and for only one no treatment was the best (2-phenylethylacetate). Models for one alcohol and three $\mathrm{C}_{6}$-compounds showed $\mathrm{a} \mathrm{r}^{2}>0.9$ using the $2^{\text {nd }}$ derived pre-treatment while two aldehydes and one terpenes showed values of $r^{2}>0.8$ using the $1^{\text {st }}$ derived. Other studies performed in 'Tannat' grapes showed lower values of $r^{2}$ in glycosylated aroma compounds (Boido et al., 2013). 


\section{Table II}

Full cross-validation statistics obtained with PLS models for volatile compounds measured in ‘Albariño’ musts by UV-VIS-NIR spectroscopy $(\mu \mathrm{g} / \mathrm{L})$

Estatísticas completas de validação cruzada obtidas com modelos PLS para compostos voláteis determinados em mostos 'Albariño' por espectroscopia UV-VIS-NIR $(\mu \mathrm{g} / \mathrm{L})$

\begin{tabular}{|c|c|c|c|c|c|}
\hline Volatile compound & Best pre-treatment data & $\mathbf{r}^{2}$ & RMSEC & RMSECV & RPD \\
\hline 1-butanol & $1^{\text {st }}$ derived & 0.53 & 7.98 & 12.71 & 0.99 \\
\hline 2+3-methyl-1-butanol & $2^{\text {nd }}$ derived & 0.59 & 64.18 & 109.27 & 0.93 \\
\hline 3 methyl -3- buten-1-ol & $2^{\text {nd }}$ derived & 0.54 & 6.62 & 10.41 & 0.93 \\
\hline 2.3-butanodiol & $2^{\text {nd }}$ derived & 0.82 & 1.44 & 3.55 & 1.69 \\
\hline Benzylic alcohol & $2^{\text {nd }}$ derived & 0.82 & 14.07 & 34.55 & 0.94 \\
\hline 2-Phenylethanol & $2^{\text {nd }}$ derived & 0.999 & 45.93 & 1550 & 0.97 \\
\hline Hexanal & $2^{\text {nd }}$ derived & 0.78 & 52.47 & 115.48 & 0.99 \\
\hline (E)-2-hexenal & $2^{\text {nd }}$ derived & 0.919 & 77.92 & 294.2 & 0.94 \\
\hline 1-hexanol & $2^{\text {nd }}$ derived & 0.9898 & 66.28 & 730.81 & 0.88 \\
\hline (E)-3-hexenol & $1^{\text {st }}$ derived & 0.47 & 9.54 & 13.31 & 0.99 \\
\hline (Z)-3-hexanol & $2^{\text {nd }}$ derived & 0.67 & 51.21 & 95.26 & 0.94 \\
\hline (Z)-2-hexanol & $2^{\text {nd }}$ derived & 0.98 & 123.25 & 738.52 & 1.05 \\
\hline (E)-2-hexanol & $2^{\text {nd }}$ derived & 0.51 & 10.69 & 15.66 & 0.93 \\
\hline Hexanoic acid & $1^{\text {st }}$ derived & 0.52 & 25.55 & 36.42 & 1.01 \\
\hline (E)-2-hexanoic acid & $2^{\text {nd }}$ derived & 0.48 & 12.79 & 16.95 & 1.07 \\
\hline Hexadecanoic acid & $2^{\text {nd }}$ derived & 0.67 & 57.22 & 99.78 & 1.01 \\
\hline 2-ethyl-hexanol & $1^{\text {st }}$ derived & 0.24 & 4.64 & 5.61 & 1.41 \\
\hline 2-Phenylethylacetate & raw & 0.63 & 6.82 & 14.25 & 1.01 \\
\hline Benzaldehyde & $1^{\text {st }}$ derived & 0.889 & 8.79 & 28.12 & 0.98 \\
\hline Phenylethanal & $1^{\text {st }}$ derived & 0.986 & 48.89 & 456.19 & 0.94 \\
\hline cis piran linalol & $1^{\text {st }}$ derived & 0.85 & 6.31 & 15.87 & 1.03 \\
\hline Diendiol I & $1^{\text {st }}$ derived & 0.587 & 11.72 & 17.62 & 1.13 \\
\hline Butyrolactone & $1^{\text {st }}$ derived & 0.49 & 15.55 & 22.8 & 0.95 \\
\hline 4-ethylphenol & $2^{\text {nd }}$ derived & 0.53 & 4.84 & 7.81 & 1.34 \\
\hline Vanillin & SNV & 0.131 & 21.78 & 25.64 & 1.04 \\
\hline Acetoin & $2^{\text {nd }}$ derived & 0.58 & 17.27 & 28.59 & 0.94 \\
\hline
\end{tabular}

Statistical parameters: Correlation Coefficient-squared $\left(\mathrm{r}^{2}\right)$, Root Mean Square of Calibration (RMSEC), Root Mean Square Error of Cross Validation (RMSECV) and Residual Predictive Deviation (RPD)

Figure 4 shows the predicted $v s$ real values of the three best models for the volatile compounds 2phenylethanol, 1-hexanol and phenylethanal by UVVIS-NIR spectroscopy. A good correlation can be observed.

Considering that $\mathrm{C}_{6}$ compounds in grape are a ripening marker, which could be a good indicator of optimal timing of harvest, the application of UV-VISNIR spectroscopy for the rapid analysis of these compounds can be new tools for winemakers to define the harvest time. High concentrations of these compounds indicate lower ripening of the grapes, providing an herbaceous aroma in future wines.

Residual predictive deviation (RPD) was used to evaluate the prediction capacity of models. RPD is the most commonly used statistical index to account for model reliability. In our study a good capacity of prediction for PLS calibrations was achieved for any volatile compounds quantified. Values around 1 were considered good for the prediction models. A total of 25 free volatile compounds from 26 showed RPD values $>0.9$. Similar results were shown by Boido et al. (2013) when they analyzed bound glicosidically compounds in 'Tannat' juice. 

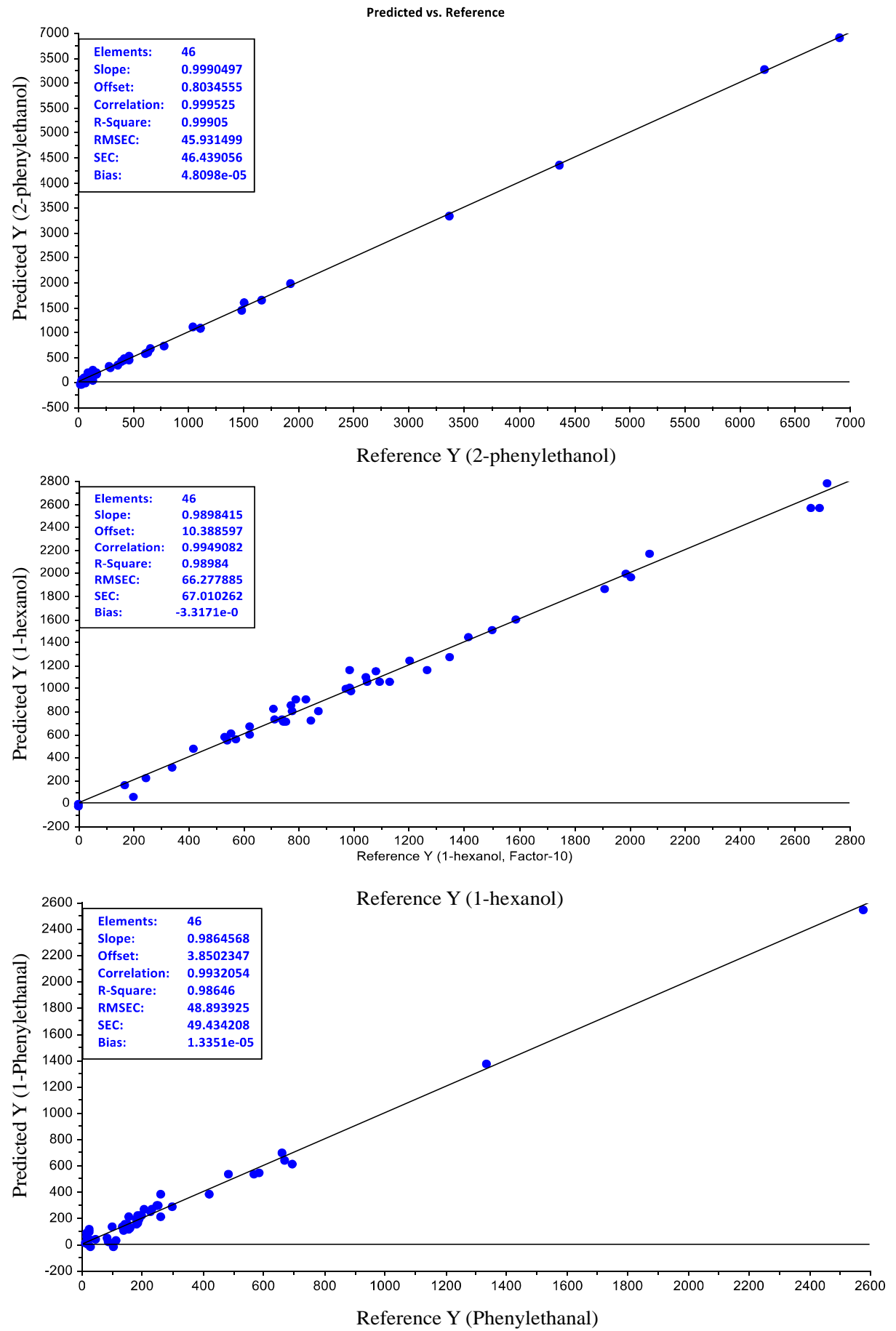

Figure 4. Prediction and real values of some volatile compounds $(\mu \mathrm{g} / \mathrm{L})$ studied in all 'Albariño' musts. 2-phenylethanol and 1-hexanol were adjusted with the $2^{\text {nd }}$ derived models and phenylethanal with the $1^{\text {st }}$ derived model. RMSEC: Root mean square of calibration; SEC: Standard error of calibration.

Valores reais e previstos de alguns compostos voláteis $(\mu \mathrm{g} / \mathrm{L})$ estudados em todos os mostos 'Albariño'. 2-fenil-etanol e 1-hexanol foram ajustados com a $2^{\text {a }}$ derivado do modelo e o feniletanal com a $1^{\text {a }}$ derivada do modelo. RMSEC: Raiz quadrada média de calibração; SEC: Erro do padrão de calibração. 


\section{CONCLUSIONS}

PLS regression models showed good results for some compounds related with grape ripening. UVVIS-NIR spectroscopy could be a rapid and nondestructive method for evaluating grape aroma during ripening and establish the harvest data. UV-

\section{REFERENCES}

Arana I., Jaren C., Arazuri S.A., 2005. Maturity, variety, and origin determination in white grapes (Vitis vinifera L.) using near infrared reflectance technology. J. Near Infrared Spectroscopy, 13, 349357.

Boido E., Fariña L., Carrau F., Dellacassa E., Cozzolino D., 2013. Characterization of Glycosylated Aroma Compounds in Tannat Grapes and Feasibility of the Near Infrared Spectroscopy Application for Their Prediction. Food Anal. Methods, 6, 100-111.

Cabassi G., Beghi R., Sinelli N., Tonesi R., Guidetti R., Casiraghi E., 2006. Valutazione rapida del grado di maturità tecnologica e fenolica del Nebbiolo di Valtellina mediante spettroscopia FT-NIR e spettroscopia Vis/NIR. In: Proc. National Conference on NearInfrared Spectroscopy (NIR Italia '06), Ferrara.

Casiraghi E., Sinelli N., Cabassi G., Beghi R., 2006. Valutazione rapida del grado di maturità tecnologica e fenolica del Nebbiolo di Valtellina mediante spettroscopia FT-NIR. In: Proc. National Conference on Near-Infrared Spectroscopy (NIR Italia '06), Ferrara.

Cetó X., Gutiérrez-Capitán M., Calvo D., del Valle M. 2013. Beer classification by means of a potentiometric electronic tongue. Food Chem., 141, 2533-2540.

Cozzolino D., Cynkar W.U., Shah N., Smith, P., 2011. Multivariate data analysis applied to spectroscopy: Potential application to juice and fruit quality. Food Res. Int., 44, 1888-1896.

Cozzolino D., Kwiatkowski M.J., Parker M., Cynkar W.U., Dambergs R.G., Gishen M., Herderich M.J., 2004. Prediction of phenolic compounds in red wine fermentations by visible and near infrared spectroscopy. Anal. Chim. Acta, 513, 73-80.

Cozzolino D., Liu L., Cynkar W.U., Dambergs R.G., Janik L., Colby C.B., Gishen M., 2007. Effect of temperature variation on the visible and near infrared spectra of wine and the consequences on the partial least square calibrations developed to measure chemical composition. Anal. Chim. Acta, 588, 224-230.

Dambergs, R.G., Cozzolino D., Cynkar W., Esler M., Janik L., Francis I.L., Hoj P., Gishen M., 2003b. Strategies to minimise matrix-related error with NIRS analysis of wine grape quality parameters. In: Proc. $11^{\text {th }}$ Intl. Conf. on Near Infrared Spectroscopy. 183-186. Davies A.M..C., Garido A.-Varo (eds.), NIR Publications, Chichester.

Dambergs R.G., Cozzolino D., Cynkar W.U., Janik L., Gishen M., 2006. The determination of red-grape quality parameters using the LOCAL algorithm. J. Near Infrared Spectroscopy, 14, 71-79.

Dambergs R.G., Cozzolino D., Esler M.B., Cynkar W.U., Kambouris A., Francis I.L., Hoj P.B., Gishen M. 2003a. The use of near infrared spectroscopy for grape quality measurement. Aust. and New Zealand Grapegr. Winemaker, 473a, 69-76.

Garde-Cerdan T., Lorenzo C., Zalacain A., Alonso, G.L., Salinas, M.R., 2012. Using near infrared spectroscopy to determine haloanisoles and halophenols in barrel aged red wines. LWT-Food Sci. Technol., 46, 401-405.
VIS-NIR spectroscopy could be a good tool for viticulture decisions in the vineyard. In conclusion, UV-VIS-NIR spectroscopy is a fast and feasible method for the determination of some volatile compounds in white 'Albariño' musts from DO Rías Baixas.

Gishen M., Dambergs B., 1998. Some preliminary trials in te application of scanning near infrared spectroscopy (NIRS) for determining the compositional quality of grapes, wine, and spirits. Austr. Grapegrow. Winemaker, 414a, 43-45.

Gishen M., Dambergs R.G., Kambouris A., Kwiatkowski M. Cynkar W.U., Høj P.B., Francis I.L., 2000. Application of near infrared spectroscopy for quality assessment of grapes, wine, and spirits. In: Proc. $9^{\text {th }}$ Intl. Conf. on Near Infrared Spectroscopy. $917-$ 920. Davies A.M.C., Giangiacomo R. (eds.), NIR Publications, Chichester.

Herrera J., Guesalaga A., Agostin E., 2003. Shortwave-near infrared spectroscopy for non-destructive determination of maturity of wine grapes. Measurement Sci. and Tech., 14, 689-697.

Kalua C.M., Boss P.K., 2009. Evolution of volatile compounds during the development of Cabernet Sauvignon grapes (Vitis vinifera L.). J. Agric. Food Chem., 57, 3818-3830.

Keckes S., Gasic U., Velickovic T.C., Milojkovic-Opsenica D., Natic M., Tesic Z., 2013. The determination of phenolic profiles of Serbian unifloral honeys using ultra-high-performance liquid chromatography/high resolution accurate mass spectrometry. Food Chem., 138, 32-40.

Lorenzo C., Garde-Cerdan T., Pedroza M.A., Alonso G.L., Salinas M.R., 2009. Determination of fermentative volatile compounds in aged red wines by near infrared spectroscopy. Food Res. Int., 42, 1281-1286

Martelo-Vidal M.J., Vázquez M., 2014. Determination of polyphenolic compounds of red wines by UV-VIS-NIR spectroscopy and chemometrics tools. Food Chem., 158, 28-34.

Martelo-Vidal M.J., Vázquez M., 2015. Application of artificial neural networks coupled to UV-VIS-NIR spectroscopy for the rapid quantification of wine compounds in aqueous mixtures. CyTA-J. Food, 13, 32-39.

Oliveira J.M., Faria M., Sá F., Barros F., Araújo, I.M., 2006. C $6^{-}$ alcohols as varietal markers for assessment of wine origin. Anal. Chim Acta, 563, 300-309.

Oliveira J.M., Maia M.O., Baumes R.L., Bayonove C.L. 2000. Free and bound aromatic components of Loureiro and Alvarinho grape varieties from the Vinhos Verdes region. Vitic, Enol. Sci., 55, 1320

Osborne B.G., Fearn T., Hindle P.H., 1993. Practical NIR Spectroscopy with Applications in Food and Beverage Analysis. 23-33 pp. Longman Scientific and Technical, Harlow.

Shenk, J., Workman J.J., Westerhaus M.O., 1992. Application of NIR spectroscopy to agricultural products. In: Handbook of NearInfrared Analysis. 383-431. $2^{\text {nd }}$ ed. Burns D.A, Ciurczak E.W. (eds.), Marcel Dekker, New York.

Smith H.E., Cozzolino D., Cynkar W.U., Dambergs R.G., Sefton M., Gishen M., 2008. Near infrared spectroscopy as a rapid tool to measure volatile aroma compounds in Riesling wine: possibilities and limits. Anal Bioanal Chem., 390, 1911-1916. 
Vilanova M., Genisheva Z., Bescansa L., Masa A., Oliveira J.M. 2009. Volatile composition of wines from Vitis vinifera Agudelo, Serradelo and Blanco lexítimo from Betanzos (NW Spain). J. Instit. Brew., 115, 35-40.
Vilanova M., Zamuz S., Vilariño F., Sieiro C. 2007. Effect of terroir on the volatiles of Vitis vinifera cv. Albariño. J. Sci. Food Agric., 87, 1252-1256. 